\title{
Pretreatment optimization, process control, mass and energy balances and economics of anaerobic co-digestion of Arachis hypogaea (Peanut) hull and poultry manure
}

\author{
S.O. Dahunsi ${ }^{\mathrm{a}, \mathrm{b}}$, S. Oranusi ${ }^{\mathrm{c}, *}$, V.E. Efeovbokhan ${ }^{\mathrm{d}}$ \\ ${ }^{a}$ Biomass and Bioenergy Group, Environment and Technology Research Cluster, Landmark University, Nigeria \\ ${ }^{\mathrm{b}}$ Biological Sciences Department, Landmark University, Omu-Aran, Nigeria \\ ${ }^{\mathrm{c}}$ Biological Sciences Department, Covenant University, Ota, Nigeria \\ ${ }^{\mathrm{d}}$ Chemical Engineering Department, Covenant University, Ota, Nigeria
}

\section{H I G H L I G H T S}

- Biogas was produced from the co-digestion of peanut hull and poultry manure.

- Thermo-alkaline pretreatment enhanced enormous biogas yield from the substrates.

- Over $70.47 \%$ gas yield was obtained with pretreatment over the untreated substrates.

- The optimal condition for maximal biogas yield were established.

- A negative energy balance was obtained which can be increased with higher loading.

\section{A R T I C L E I N F O}

\section{Article history:}

Received 24 April 2017

Received in revised form 18 May 2017

Accepted 25 May 2017

Available online 29 May 2017

\section{Keywords:}

Anaerobic digestion

Biogas

Energy balance

Microorganisms

Modeling

Peanut

\begin{abstract}
A B S T R A C T
The study explored biogas production from the co-digestion of Arachis hypogaea hull and poultry droppings. Mechanical and thermo-alkaline pretreatments were applied to a sample of the mixture. Another sample was treated mechanically but without thermo-alkaline methods. Optimization was done using the Response Surface Methodology (RSM) and the Artificial Neural Networks (ANNs). The optimal values for each of the five major parameters optimized are Temperature of $32.00{ }^{\circ} \mathrm{C}, \mathrm{pH}$ of 7.62 , Retention time of 30.00 day, Total solids of $12.00 \mathrm{~g} / \mathrm{kg}$ and Volatile solids of $10.00 \mathrm{~g} / \mathrm{kg}$ and the predicted biogas yield for RSM was $3903.1510^{-3} \mathrm{~m}^{3} / \mathrm{kg}$ TSfed and $3338.310^{-3} \mathrm{~m}^{3} / \mathrm{kg}$ TSfed for ANNs in the thermoalkaline pretreated experiment. Gas chromatography show the $\mathrm{CH}_{4}$ and $\mathrm{CO}_{2}$ content of biogas generated to be $65.5 \pm 1.5 \% ; 26 \pm 1 \%$ and $53 \pm 1 \% ; 26 \pm 2 \%$ respectively. The co-digestion of peanut hull with poultry droppings and other energy-yielding substrates is further encouraged.
\end{abstract}

(c) 2017 Elsevier Ltd. All rights reserved.

\section{Introduction}

Anaerobic digestion (AD) is a technology widely applied in the treatment of lignocellulosic biomass in order to generate methane gas and a nutrient-rich final digestate (Maus et al., 2016; Dahunsi et al., 2017a). The digestion efficiency of these biomass is however largely limited due to the relatively rate-limiting hydrolysis stage caused by a network of complex cellulose-hemicellulose-lignin matrix making them resistant to enzymatic attack and biodegradation by anaerobic microorganisms (Jaffar et al., 2016). Pretreatment of lignocelluloses is therefore necessary in order to achieve among

\footnotetext{
* Corresponding author.

E-mail address: solomon.oranusi@covenantuniversity.edu.ng (S. Oranusi).
}

others the solubilization of lignin and hemicelluloses and a higher yield of biogas (Abudi et al., 2016). Besides, lignin is the most rigid component of plant biomass with the ability to bind tightly to cellulose and hemicellulose thereby providing a physical seal around them and further protects them against enzymatic attack (Cesarino et al., 2012; Fang et al., 2014).

Different pretreatment methods have been investigated with the view of overcoming the afore-mentioned limitations. These include physical, mechanical, ultrasonic, biological and thermoalkaline pretreatments. Application of these treatments has been reported to improve $\mathrm{AD}$ efficiency via the disruption of biomass structural components in order to release the intracellular nutrients and increase in the concentration of soluble chemical oxygen demand (sCOD) all leading to improved methane production (Fang 
et al., 2014). Among these various pretreatment methods, alkaline pretreatment have proved to be more advantageous over others in terms of simplicity in materials and operation coupled with higher efficiency in methane generation. In their study, Costa et al. (2014) reported that the use of alkaline pretreatment methods was efficient in delignification, fiber expansion and also increased the pore size and accessible surface area of lignocellulosic biomass thereby facilitating the diffusion of hydrolytic enzymes. Another advantage of alkaline treatment is its ease of combination with other methods including thermal, ultrasound and microwave with the aim of maximizing biomass valorization and higher methane yield than in the single pretreatment application (Jang and Ahn, 2013).

Experimentally, temperature ranging from 50 to $250{ }^{\circ} \mathrm{C}$ has been employed for the pretreatment of lignocellulosic biomass. In most studies, temperatures $>150{ }^{\circ} \mathrm{C}$ led to excessive lignin solubilization and the release of inhibitory phenolic compounds which are usually toxic to microbial cells. It can also lead to formation of complex substances e.g. the reaction between simples sugars and amino acids (Mallaird reaction) resulting in the formation of complex inhibitory substances that adversely affect the rate of anaerobic degradation (Carrere et al., 2010; Elliot and Mahmood, 2012). The success of thermal pretreatment therefore depends on the substrate and the adopted temperature range.

Similarly, temperatures of $\leq 100^{\circ} \mathrm{C}$ over a longer treatment time has been considered for lignocellulosic biomass. Most treatments at $100{ }^{\circ} \mathrm{C}$ failed to achieve the desired substance degradation and increased biogas yield (Protot et al., 2011). On the contrary, pretreatment at $70^{\circ} \mathrm{C}$ led to higher yield of biogas in some studies (Appels et al., 2010; Chamchoi et al., 2011).

Arachis hypogaea (Peanut) hulls are important agro-industrial lignocellulosic biomass abundant worldwide due to the global increase in peanut production. For example, production in the United States (North America) alone was increased by up to $45 \%$ within a year (2011 and 2012) giving rise to 3.04 million metric tons in production (Agricultural Marketing and Resource Center, 2015). In Brazil (South America), an annual production of around 320,000 tons was generated in 2014 also giving more than 90,000 tons of the hulls (Polachini et al., 2016). In China (Asia), annual production is about 13 million tons with approximately 3.64 million tons hulls being generated (USDA, 2014; Wang et al., 2016). In Nigeria (Africa), total production of 8.7 million metric tons was recorded in Nigeria alone in 2011 from a total harvested area of 9.04 million ha (FAOSTAT, 2013). Approximately 45.6 million metric tons of Arachis hypogaea are produced worldwide annually and it has been estimated that for every $\mathrm{kg}$ of peanuts produced, between 230 and $300 \mathrm{~g}$ of the hulls is derived making a total of approximately 13.7 million metric tons of peanut hulls emanating from the production areas annually and which usually end up in the waste bin (FAOSTAT, 2015). Therefore, the hulls if well managed are reputable sources of renewable and sustainable biofuels even though only few value-added applications have been sought for them prior to this research. This calls for more intensified efforts in establishing environmental sustainable uses for this abundant resource.

The hulls are composed mainly of lignin, cellulose and hemicellulose. Analysis has shown that peanut hulls composed of about 43\% lignin (Fang et al., 2014) and this is far higher than the values obtainable in other agricultural biomass e.g. rice and wheat straws, sunflower shoot, sugar cane bagasse, corn stover etc (Fang et al., 2014; Iqbal et al., 2013). This is the major issue militating against the profound usage of the hull for biofuels as the high lignin content makes them recalcitrant to microbial degradation both in natural and controlled environment. It has been reported that co-digestion with other substrates is a veritable way of maximizing peanut hulls in biofuel generation (Anike et al., 2016). Though biogas generation from poultry manure is well reported, the major challenge encountered often is the inhibition posed by the low $\mathrm{C} / \mathrm{N}$ ratio and super richness in nitrogen and ammonia compounds (Tian et al., 2015). The best approach therefore is co-digestions with other energy-yielding substrates as this will enhance substrate synergy and higher microbial diversity leading ultimately to higher biogas yield (Khoufi et al., 2015). Despite the abundance of peanut hulls globally, only few attempts have been documented for its utilization for biofuel generation and such studies focused majorly on ethanol and isoprene productions (Herring and Narayanan, 2016; Polachini et al., 2016; Wang et al., 2016) while its usage for biogas generation is grossly under-reported. Though the potential of the hull for biogas generation in mono-digestion was reported in our recent study (Dahunsi et al., 2017b), the potential synergistic effects in its co-digestion with other substrates in order to improve digestibility and biogas yield is yet to be understood and this was addressed in this research.

\section{Materials and methods}

\subsection{Collection of sample and pretreatment}

Hulls of A. hypogaea were collected from the Landmark University Farms, Omu-Aran, Kwara State, Nigeria after peanut harvest and subsequent dehulling to separate the nuts. In the bid to overcome the rate-limiting phenomenon often encountered during $\mathrm{AD}$ hydrolysis and in order to reduce the lignocellulosic matrix of the peanut hulls, pretreatment was applied prior to digestion according to earlier methods that combined mechanical, thermal and alkaline procedures (Dahunsi et al., 2016a,b). The hulls were mechanically crushed with the aid of a hammer mill to mesh size of $\leq 20 \mathrm{~mm}$. Immediately following this was thermal treatment (heating) at $80^{\circ} \mathrm{C}$ for 70 min using the CLIFTON 88579 water bath (Nickel-Electro Ltd., England). Before determining the appropriate temperature and duration of thermal treatment, an experiment design was done via the Central Composite Design (CCD) according to the method of Zou et al. (2016). A two-factor design was adopted accommodating (i) the pretreatment time and (ii) the pretreatment temperature for A. hypogaea's hulls. A time variation between 50 and $70 \mathrm{~min}$ and pretreatment temperature of between $70{ }^{\circ} \mathrm{C}$ and $200{ }^{\circ} \mathrm{C}$ were chosen.

After heating was alkaline pretreatment which was carried out using $3 \mathrm{~g} \mathrm{NaOH} / 100 \mathrm{~g}$ TS at $55^{\circ} \mathrm{C}$ for a $24 \mathrm{~h}$ period and at a solid loading of $35 \mathrm{~g} \mathrm{TS} \mathrm{L}^{-1}$. NaOH is widely reported as the most efficient alkali in thermo-alkaline pretreatment of biomass hence its usage in this research (Li et al., 2015). A control experiment tagged as "untreated" was set up to run alongside the thermo-alkaline pretreated set up in which the same substrate (A. hypogaea hull) was digested with prior mechanical grinding but without thermo-alkaline pretreatments. This was to assess the efficiency of thermo-alkaline pretreatments in terms of nutrient availability, microbial diversity and digestion in the pretreated substrate. After pretreatment, the substrates in both set ups were digested using a set of 25-litre sized digesters furnished with in-built mechanical stirrer for adequate mixing of substrate during AD. Liquid displacement apparatus were coupled to each air-tight digestion tank for collection of produced gas (Dahunsi and Oranusi, 2013; Alfa et al., 2014b; Dahunsi et al., 2016a,b).

\subsection{Experimental design via CCD and Artificial Neural Networks (ANNs)}

Similar to the experimental design for standardizing the pretreatment conditions, the AD of A. hypogaea hull in both experiments was designed using the CCD. The use of this tool for experimental design in bioprocessing and $\mathrm{AD}$ is well reported 
(Montingelli et al., 2016). Five important process parameters were chosen for modeling and optimization thus forming a Five-levelfive-factors factorial design that generated a total of 50 experimental runs as shown in Tables S1 and S2 (Supplementary material). The parameters were Temperature $\left({ }^{\circ} \mathrm{C}\right), \mathrm{pH}$, Retention time (days), Total solids $(\mathrm{g} / \mathrm{kg})$ and Volatile solids $(\mathrm{g} / \mathrm{kg})$ represented with $\boldsymbol{V}, \boldsymbol{W}$, $\boldsymbol{X}, \boldsymbol{Y}$ and $\boldsymbol{Z}$. The selection of these factors was based on the need to standardize the $\mathrm{AD}$ process and this is very vital during scale-up of the AD process using same substrate. A good number of previous researches have reported values for these parameters based on the substrate used and the condition of digestion. For example, most mesophilic $\mathrm{AD}$ have been operated at temperature of between 30 and $40{ }^{\circ} \mathrm{C}$ (Dahunsi et al., 2017c,d) while pH values have usually ranged between 6.5 and 8.0 (Zonta et al., 2013; Leite et al., 2016). For the retention time, duration of between 20 and 30 days is well reported in literature basically because this parameter is largely affected by the ambient temperature (Mao et al., 2015). A total solid content $<15 \%$ and $\geq 4 \%$ is well reported for liquid AD (Dahunsi et al., 2017a,b,c,d). As one of the major objectives of this study was to document the optimal condition for the efficient $\mathrm{AD}$ of $A$. hypogaea hull and poultry droppings, all the afore-mentioned range of values were put to the test and the results are as reported in the results section. After obtaining data via the $C C D$, ANN module was also employed to analyze the data using the Neural Power version 2.5 (CPC-X software). The purpose was to select data that were statistically well distributed as shown in Figs. S1 and S2 (Supplementary material).

\subsection{Methane potential tests}

The methane production potential of the mixture of $A$. hypogaea hull and poultry droppings was determined at standard temperature and pressure (STP) following standard methods in a 30-day batch anaerobic experiment (Dahunsi et al., 2016a,b). Three (3) digesters i.e. two experimental and a blank were used in triplicate with an inoculum to substrate ratio of 2 . Generated gas was continuously collected after which chromatographic analyses were done to quantify the methane content. The Residual methane test was carried out on the anaerobic digestates following the same method (Dahunsi et al., 2017c,d).

\subsection{Digestion}

For the $\mathrm{AD}$ of both thermo-alkaline pretreated and untreated mixture of A. hypogaea hull and poultry droppings, a total of eight $\mathrm{kg}$ of substrate was diluted with water at a solid loading of $35 \mathrm{~g} \mathrm{TS} \mathrm{L}^{-1}$ to form slurry to which was added 1.6 liters of inoculum and the entire slurry (approximately 17.5 liters) was charged into each digestion tank via the specialized inlet (Alfa et al., 2014a). The efficiency of the anaerobic treatment of the substrates was confirmed periodically by daily recording of average temperature, weekly $\mathrm{pH}$ recording, and daily measurement of gas production, weekly microbial succession assessment and chemical analyses of fermenting substrates as well as those of the digestates at the end of the retention time. Characterization of collected gas was done in order to quantify the methane $\left(\mathrm{CH}_{4}\right)$ and $\mathrm{CO}_{2}$ contents with the aid of a HP 5890 Gas Chromatography (Avondale, USA) which had an attached Hayesep Q column $(13 \mathrm{~m} \times 0.5 \mathrm{~m} \times 1 / 800)$ and a flame ionization detector (FID) (Dahunsi et al., 2017b).

\subsection{Analytical methods}

Chemical analyses were carried out on the substrates so as to quantify their elements/nutrients composition before digestion. These were also conducted on the inoculum and the resulting digestates after the digestion. Evaluations of all parameters were done following standard protocols and were carried out in the Environmental Engineering laboratory of Landmark University. Before analyses, a sample of both the thermo-alkaline pretreated and the untreated substrates were centrifuged in order to separate the liquid from the solid portion that was subsequently used for analyses of all parameters except total phenol determination. For the determination of parameters such as Total Carbon (TC), Total Nitrogen (TN), Total Phosphorus (TP), Potassium (K), Phosphates $\left(\mathrm{PO}_{4}\right)$, Sulphates $\left(\mathrm{SO}_{4}\right)$ Sodium ( $\left.\mathrm{Na}\right)$, Magnesium $(\mathrm{Mg})$, Calcium $(\mathrm{Ca})$, Nitrates $\left(\mathrm{NO}_{3}\right)$, Iron (Fe), Copper $(\mathrm{Cu})$, Zinc $(\mathrm{Zn})$, Aluminium $(\mathrm{Al})$ and Manganese $(\mathrm{Mn})$, the Palintest ${ }^{(\mathrm{R})}$ Photometer 7500 (PHOT.1.1.AUTO.75) advanced digital-readout colorimeter (Camlad, Cambridge, United Kingdom) were used following earlier established protocol (Dahunsi et al., 2016a,b, 2017a,b). In using the instrument, an absorbance of 0.5 at $450 \mathrm{~nm}$ wavelength was used. The Standard Methods for analyses of water and wastewaters used by Dahunsi et al. (2014) was used in determining the COD of the samples. The total phenolic contents of the samples were determined using a microtube test (Spectroquant, Merck) closely followed by a 4-aminoantipyrine colorimetric measurement (Monlau et al., 2015). The TS content were determined by drying samples to constant weight at $105^{\circ} \mathrm{C}$ while for VS, known weights of dried samples were ignited to constant weight at $575 \pm 25^{\circ} \mathrm{C}$ (Wang et al., 2016). Soluble sugars (sucrose and inulin) were extracted using a mild acid hydrolysis protocol after which the anthrone method was used to do further quantification (Dahunsi et al., 2017b). On the other hand, a strong acid hydrolysis protocol earlier described (Monlau et al., 2015) was used to quantify structural carbohydrates (glucose, xylose and arabinose) as well as uronic acids (galacturonic and glucuronic acids). The Klason method was used for lignin content determination. In doing this, $100 \mathrm{mg}$ dried samples were hydrolyzed with $12 \mathrm{M} \mathrm{H}_{2} \mathrm{SO}_{4}$ for $1 \mathrm{~h}$ at room temperature and then diluted to reach a final acid concentration of $1.5 \mathrm{M}$. This solution was kept at $100{ }^{\circ} \mathrm{C}$ for $2 \mathrm{~h}$ and the hydrolysates were centrifuged at 10,000 rpm for $10 \mathrm{~min}$ (Monlau et al., 2012). Thereafter, the Klason lignin content was determined as the weight of the residue. The cellulose and hemicelluloses content was determined based on the monomeric sugar contents.

\subsection{Microbial assessment}

\subsubsection{Aerobic and anaerobic enumeration}

Aerobic bacteria involved at every stage of the AD were isolated and characterized following standard methods with specific media. Biochemical and phenotypic methods were used in the identification and suspected candidates were confirmed with the aid of appropriate rapid API kits (BioMerieux). Fungal organisms were isolated by culturing samples on Potato dextrose agar (PDA) and the dynamics of fungal hyphae, structures/morphology of cell spores and the nature of their fruiting bodies were employed in their identification. Facultative Clostridium species and other anaerobic acidogens were isolated anaerobically using two important media (Reinforced Clostridia medium and blood agar) at temperature of $37^{\circ} \mathrm{C}$ for approximately one week. Biochemical procedures were followed in the preliminary characterization and the suspected isolates were identified using appropriate rapid API kits as reported (Ayandiran and Dahunsi, 2017). All analyses were carried out weekly in triplicates in the Microbiology laboratory of Biological Sciences Department, Covenant University, Ota, Nigeria.

\subsubsection{Enumeration of methanogen (archaea)}

A mineral-rich medium was compounded and used for the evaluation of members of the archaea following earlier description by Ghosh et al. (2014). The basal medium (BM) used contained minerals, trace elements and dyes such as $\mathrm{NH}_{4} \mathrm{Cl}, \mathrm{KH}_{2} \mathrm{PO}_{4}, \mathrm{MgCl}_{2}$ - 
$.6 \mathrm{H}_{2} \mathrm{O}, \mathrm{CaCl}_{2} \cdot 2 \mathrm{H}_{2} \mathrm{O}, \mathrm{NaHCO}_{3}$, sodium resazurin dye, $\mathrm{Na}_{2} \mathrm{~S}$, cysteine$\mathrm{HCl}$, and sodium-thioglycolate all prepared under anoxic environment with double distilled water having 7.0 final $\mathrm{pH}$. To this prepared $\mathrm{BM}$ was added a supplement solution, $\mathrm{NaHCO}_{3}$, cysteine- $\mathrm{HCl}$ and $\mathrm{FeSO}_{4}$ in $\mathrm{H}_{2} \mathrm{SO}_{4}$. The supplement solution added to the $\mathrm{BM}$ also contained vitamins and trace elements which were all dissolved in double distilled water. The basal medium, $\mathrm{FeSO}_{4}$, and the supplement solution were separately autoclaved and then mixed with the $\mathrm{NaHCO}_{3}$ and cysteine- $\mathrm{HCl}$ which had earlier been filter sterilized. All the liquid media were rid of dissolved oxygen by flushing with nitrogen gas until the resazurin (indicator dye) turned colorless.

\subsection{Energy balance and efficiency assessment of thermo-alkaline pretreatment application}

The need arose to assess the balance in energy generation and consumption so as to ascertain the economic feasibility of applying thermo-alkaline pretreatment to the substrate in this study. In computing the balance, the additional cost of obtaining heat energy and for $\mathrm{NaOH}$ purchase was compared with the surplus energy obtained through the thermo-alkaline pretreatment application so as to determine if the extra gas yield obtained as a result of pretreatment will be enough to cover the initial expenses. The thermal energy required (TER) in $\mathrm{kWh} \mathrm{t}^{-1}$ TS to pretreat one ton TS of $A$. hypogaea hull at a temperature of $55^{\circ} \mathrm{C}$ was computed using the simple equation shown below:

$\mathrm{TER}=\frac{w \times S h *(\text { T final }- \text { Tinitial })}{3600}$

where $w(1000 \mathrm{~kg})=$ mass of the mixture of substrate and water $(\mathrm{kg})$; $S h=$ specific heat of water i.e. $4.18 \mathrm{~kJ} \mathrm{~kg}^{-1} \mathrm{C}^{-1} ; T$ initial $\left({ }^{\circ} \mathrm{C}\right)$ $=$ the initial temperature of substrate i.e. $25^{\circ} \mathrm{C} ; \mathrm{T}$ final $\left({ }^{\circ} \mathrm{C}\right)=$ the final substrate temperature i.e. $55^{\circ} \mathrm{C}$. The European Union cost of $412 € /$ ton was used to account for the purchase of $\mathrm{NaOH}$ (Monlau et al., 2015).

\subsection{Statistical data analysis}

After the digestion of both substrates, the obtained data were statistically analyzed using the RSM as this would allow fitting of the generated quadratic polynomial equation. Multiple regressions were employed in fitting the coefficient of the polynomial model of the response thereby correlating the response variable to all the five independent variables used in the modeling and optimization. Thereafter, the significance test and analysis of variance (ANOVA) were used to fit the model quality as shown in Eq. (2):

$Y=b_{0}+\sum_{i=1}^{k} b_{i} \times i+\sum_{i=1}^{k} b_{i i} \times_{i}^{2}+\sum_{i<j}^{k} b_{i j} \times_{i} \times_{j}+e$

where: $Y=$ the response variable; $b_{o}=$ intercept value; $b_{i}(\mathrm{i}=1,2, \mathrm{k})$ $=$ the first order model coefficient; $b_{i j}=$ the interaction effect; $b_{i i}=-$ the quadratic coefficients of $\mathrm{X}_{\mathrm{i}}$ while $e=$ the random error. Further statistical analysis of data obtained from the CCD was done using the ANNs. The optimum structure of the ANNs was determined using the mean square error (MSE) approach thereby also determining the higher coefficient of determination $\left(\mathrm{R}^{2}\right)$. Three-dimensional curvature plots and relative importance were used to carry out variable analysis so as to study the effects of the variables on the biogas yield. Comparison was made between the results of the RSM and ANNs after modeling. Both models were validated using same digesters employed in the AD processes for 3 independent replicates after which the fits showing the deviations of actual from observed values were plotted.

\section{Results and discussion}

\subsection{Thermo-alkaline pretreatment's effects on the structural composition of A. hypogaea hull}

Table 1 shows the results of all the structural compositions in the thermo-alkaline treated and untreated substrates and the raw $A$. hypogaea hull before and after digestion. In the mixture of pretreated A. hypogaea hull and poultry droppings, the thermoalkaline pretreatment has succeeded in reducing the composition of both cellulose and hemicelluloses by $30 \%$ in each case while those of lignin and uronic acids were $31.48 \%$ and $41.43 \%$ respectively. For the soluble sugars, a $41 \%$ increase in their concentration was observed in the thermo-alkaline pretreated experiment.

\subsection{Digestion stability and performance evaluation}

Biogas generation in the methane potential tests commenced on the 2nd and 4th experimental days respectively in the thermo-alkaline pretreated and untreated set ups with $\mathrm{CH}_{4}$ and $\mathrm{CO}_{2}$ contents of $64 \pm 2 \% ; 26 \pm 1 \%$ and $53 \pm 1 \% ; 26 \pm 2 \%$ in both experiments. Further shown in Table 1 are the analytical results of the entire important chemical and few physical parameters carried out on the substrates prior to and after the AD. An initial decline from alkaline to slightly acidic $\mathrm{pH}$ was observed during the first week of digestion, the $\mathrm{pH}$ in both experiments remained within slightly alkaline range throughout the AD process (Fig. 1). As for temperature, mesophilic range was observed throughout the experiment in both set ups. Chemical parameters analysis revealed increase in the values of most parameters at the end of the $\mathrm{AD}$ with higher values recorded in the pre-treated over the untreated samples. However, reductions were recorded for total and volatile solids due to degradation to form biogas and in total carbon and calcium due to uptake for microbial metabolism and cell wall synthesis. The raw $A$. hypogaea hull, poultry droppings and the untreated sample (A. hypogaea hull + poultry droppings) were all shown to be low in $\mathrm{C} / \mathrm{N}$ ratio with values between 5 and 13. Only the thermo-alkaline pretreated sample recorded a reasonably high ratio of 16 . Reductions of 61.21 and $40.51 \%$ were also recorded for COD in both set ups after completion of the AD.

\subsection{Volatile fatty acids (VFAs) dynamics}

Table 1 also shows the dynamics of the VFAs which are the intermediate products during microbial degradation of substrates and therefore are the most reported $\mathrm{AD}$ inhibitors. Their concentration is affected by the production rate and/or consumption by AD microbial community. In this study, VFAs accumulation was negligible during the early days of digestion and this was recorded in both experiments. As the experiments progressed, accumulation at low levels were observed from the 9th day and continued till the 15th day of digestion. The implication of this is that there was an imbalance between the two major stages of digestion i.e. hydrolysis/acidogenesis and acetogenesis/methanogenesis. Acetate and propionate were the two dominating acids implicated in the experiment produced in both experiments whose concentrations accounted for over $90 \%$ of total VFA in terms of COD concentration. Also, acetate's consumption was much faster than propionate and the degradation of the latter commenced after the former was almost completely degraded. The highest total VFA accumulation was observed on the 12 th and 14th days in the thermo-alkaline pretreated and untreated experiments respectively. Similarly, ammonia $\left(\mathrm{NH}_{3}\right)$ concentration reached the highest concentration between the 10th and 12th days of digestion in both experiments before subsequent reduction for the remaining part of the digestion process. 
Table 1

Physical and chemical characteristics of Arachis hypogaea hulls, poultry droppings before and after digestion.

\begin{tabular}{|c|c|c|c|c|c|c|}
\hline \multirow[t]{2}{*}{ Parameters } & \multirow[t]{2}{*}{ Poultry droppings } & \multirow[t]{2}{*}{ Raw A. hypogaea hull } & \multicolumn{2}{|c|}{$\begin{array}{l}\text { Pretreated A. hypogaea hull + Poultry } \\
\text { droppings }\end{array}$} & \multicolumn{2}{|c|}{$\begin{array}{l}\text { Untreated A. hypogaea hull + Poultry } \\
\text { droppings }\end{array}$} \\
\hline & & & Before Digestion & After digestion & Before Digestion & After digestion \\
\hline $\mathrm{pH}$ & $6.90 \pm 0.22$ & $6.71 \pm 0.10$ & $7.70 \pm 0.20$ & $7.65 \pm 0.01$ & $7.73 \pm 0.01$ & $7.66 \pm 0.02$ \\
\hline Total Solids (g/kg TS) & $281.24 \pm 1.02$ & $93.13 \pm 0.12$ & $100.00 \pm 0.02$ & $76.00 \pm 1.01$ & $119.51 \pm 3.00$ & $104.31 \pm 1.02$ \\
\hline Volatile Solids (g/kg TS) & $229.71 \pm 1.13$ & $72.61 \pm 0.20$ & $96.39 \pm 0.02$ & $46.83 \pm 1.01$ & $99.52 \pm 5.03$ & $72.36 \pm 4.00$ \\
\hline Ash Content (\%) & $18.29 \pm 2.11$ & $7.32 \pm 0.26$ & $3.61 \pm 0.21$ & $4.17 \pm 0.01$ & $2.31 \pm 1.02$ & $3.71 \pm 1.00$ \\
\hline Moisture Content (\%) & $71.76 \pm 2.80$ & $82.90 \pm 3.02$ & $90.00 \pm 0.01$ & $93.62 \pm 1.01$ & $80.97 \pm 1.01$ & $89.54 \pm 3.10$ \\
\hline Total Carbon (g/kg TS) & $292.10 \pm 3.10$ & $342.20 \pm 2.03$ & $698.21 \pm 0.02$ & $585.52 \pm 0.01$ & $452.91 \pm 4.11$ & $374.88 \pm 5.10$ \\
\hline Total Nitrogen ( $\mathrm{g} / \mathrm{kg} \mathrm{TS})$ & $61.00 \pm 1.12$ & $34.08 \pm 1.06$ & $43.00 \pm 0.02$ & $46.70 \pm 1.00$ & $34.52 \pm 2.01$ & $36.21 \pm 1.01$ \\
\hline $\mathrm{C} / \mathrm{N}$ Ratio & $5 / 1$ & $10 / 1$ & $16 / 1$ & $12 / 1$ & $13 / 1$ & $10 / 1$ \\
\hline Acetate (g COD/g VS) & $1.16 \pm 0.01$ & $0.01 \pm 0.10$ & $0.13 \pm 0.10$ & $0.005 \pm 0.01$ & $0.10 \pm 0.01$ & $0.006 \pm 0.10$ \\
\hline Propionate (g COD/g VS) & $1.17 \pm 0.10$ & $0.03 \pm 0.02$ & $0.12 \pm 0.03$ & $0.004 \pm 0.01$ & $0.11 \pm 0.01$ & $0.005 \pm 0.11$ \\
\hline TVFAs (g COD/g VS) & $3.33 \pm 0.12$ & $0.05 \pm 0.10$ & $0.29 \pm 0.10$ & $0.14 \pm 0.10$ & $0.18 \pm 1.10$ & $0.10 \pm 0.01$ \\
\hline Ammonia (mg/g VS) & $16.23 \pm 2.00$ & $0.73 \pm 0.01$ & $5.24 \pm 0.05$ & $2.04 \pm 0.01$ & $3.58 \pm 1.11$ & $2.23 \pm 0.11$ \\
\hline COD (g COD/g VS) & $228.98 \pm 3.00$ & $120.15 \pm 1.01$ & $260 \pm 0.23$ & $112.09 \pm 1.01$ & $294.12 \pm 5.01$ & $122.61 \pm 0.21$ \\
\hline Cellulose (\% VS) & $4.11 \pm 1.10$ & $39.15 \pm 1.10$ & $25.40 \pm 0.01$ & $19.22 \pm 1.10$ & $43.15 \pm 2.10$ & $36.35 \pm 1.02$ \\
\hline Hemicelluloses (\% VS) & $1.51 \pm 1.11$ & $23.23 \pm 0.10$ & $15.05 \pm 1.01$ & $11.71 \pm 0.50$ & $25.41 \pm 1.10$ & $21.93 \pm 1.10$ \\
\hline Klason lignin (\% VS) & $7.08 \pm 1.05$ & $44.25 \pm 0.15$ & $24.56 \pm 1.20$ & $21.44 \pm 1.10$ & $48.92 \pm 3.00$ & $44.76 \pm 1.05$ \\
\hline Uronic acids (\% VS) & $0.51 \pm 1.10$ & $2.51 \pm 1.10$ & $1.47 \pm 1.10$ & $0.79 \pm 2.01$ & $2.82 \pm 1.10$ & $1.11 \pm 0.10$ \\
\hline${ }^{\circledR}$ Soluble sugars (\% VS) & $2.65 \pm 1.05$ & $4.50 \pm 0.02$ & $7.62 \pm 1.01$ & $12.12 \pm 0.10$ & $5.16 \pm 0.10$ & $7.13 \pm 1.10$ \\
\hline Phenols ( $\mathrm{mg} \mathrm{L}^{-1}$ ) & $1.00 \pm 0.01$ & - & $15.27 \pm 0.15$ & $23.09 \pm 1.01$ & - & $19.51 \pm 0.10$ \\
\hline Total Phosphorus (g/kg TS) & $7.90 \pm 0.12$ & $3.65 \pm 0.01$ & $6.00 \pm 0.20$ & $8.20 \pm 0.20$ & $4.61 \pm 1.01$ & $5.53 \pm 0.11$ \\
\hline Potassium (g/kg TS) & $9.00 \pm 0.00$ & $5.21 \pm 0.02$ & $8.2 \pm 0.12$ & $9.60 \pm 0.21$ & $5.33 \pm 0.01$ & $7.79 \pm 2.01$ \\
\hline Phosphate (g/kg TS) & $3.80 \pm 0.10$ & $1.80 \pm 0.40$ & $3.10 \pm 0.02$ & $4.00 \pm 0.20$ & $1.64 \pm 0.50$ & $2.71 \pm 2.01$ \\
\hline Sulphate (g/kg TS) & $164.00 \pm 3.02$ & $101.02 \pm 3.00$ & $142.00 \pm 0.21$ & $178.00 \pm 0.12$ & $118.54 \pm 3.01$ & $126.80 \pm 0.01$ \\
\hline Calcium (g/kg TS) & $44.00 \pm 0.02$ & $92.02 \pm 3.02$ & $98.80 \pm 3.01$ & $68.00 \pm 0.20$ & $74.50 \pm 1.05$ & $59.50 \pm 1.05$ \\
\hline Magnesium (g/kg TS) & $150.00 \pm 2.10$ & $62.21 \pm 2.05$ & $100.0 \pm 0.01$ & $116.00 \pm 0.12$ & $82.7 \pm 0.01$ & $90.0 \pm 2.00$ \\
\hline Manganese (g/kg TS) & $0.040 \pm 0.01$ & $0.13 \pm 0.01$ & $0.030 \pm 0.02$ & $0.042 \pm 0.02$ & $0.015 \pm 0.01$ & $0.023 \pm 0.01$ \\
\hline Iron $(\mathrm{g} / \mathrm{kg} \mathrm{TS})$ & $1.46 \pm 0.02$ & $0.11 \pm 0.01$ & $1.18 \pm 0.20$ & $1.64 \pm 0.02$ & $0.92 \pm 0.01$ & $1.08 \pm 0.01$ \\
\hline Zinc (g/kg TS) & $51.00 \pm 2.02$ & $31.29 \pm 0.01$ & $39.00 \pm 0.22$ & $51.00 \pm 0.12$ & $31.05 \pm 0.01$ & $35.19 \pm 0.04$ \\
\hline Aluminium (g/kg TS) & $0.62 \pm 0.30$ & $0.03 \pm 0.01$ & $0.100 \pm 0.01$ & $0.94 \pm 0.02$ & $0.67 \pm 0.01$ & $0.73 \pm 0.02$ \\
\hline Copper (g/kg TS) & $5.80 \pm 0.72$ & $3.00 \pm 0.01$ & $4.90 \pm 0.21$ & $6.40 \pm 0.02$ & $4.12 \pm 0.03$ & $4.40 \pm 0.04$ \\
\hline
\end{tabular}

$\mathrm{N}=120 ; \pm=$ Standard deviation.

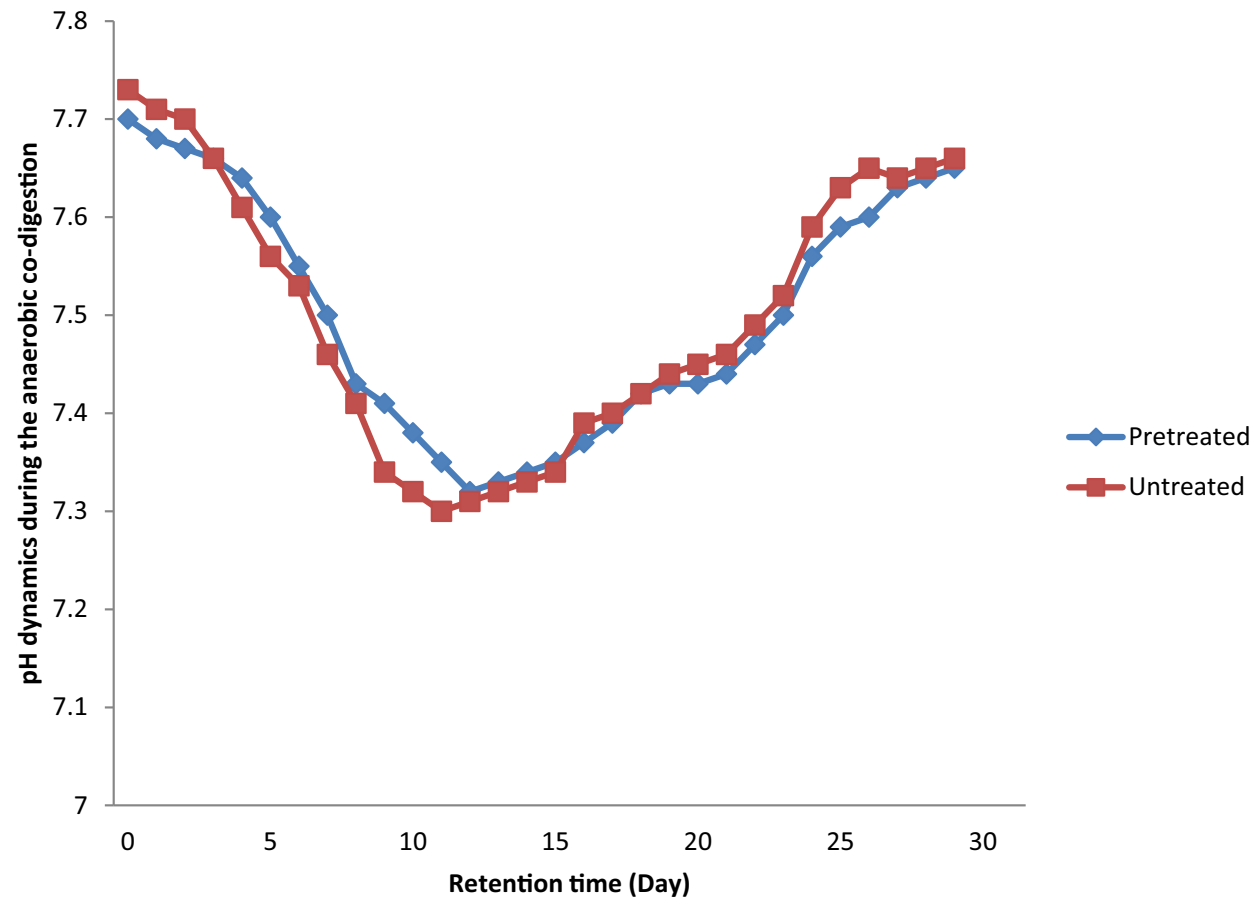

Fig. 1. pH fluctuations in the anaerobic co-digestion of the two samples of Arachis hypogaea + poultry dropping.

\subsection{Pretreatment optimization and biogas production}

Table 2 shows the experimental design for the applied thermoalkaline pretreatments. From the table, the optimum pretreatment condition was temperature of $80^{\circ} \mathrm{C}$ for a period of $70 \mathrm{~min}$ and this gave the highest yield of biogas i.e. $1819.89 \mathrm{~m}^{3} / \mathrm{kg}$ TSfed for the mono-digestion of A. hypogaea hull (Dahunsi et al., 2017b) and $3903.15 \mathrm{~m}^{3} / \mathrm{kg}$ TSfed for the co-digestion with poultry droppings. 
Table 2

Experimental design of peanut hull pretreatment prior to digestion.

\begin{tabular}{|c|c|c|c|c|}
\hline Sample & $\begin{array}{l}\text { Pre-treatment } \\
\text { temperature } \\
\left({ }^{\circ} \mathrm{C}\right)\end{array}$ & $\begin{array}{l}\text { Pre-treatment } \\
\text { time (Min) }\end{array}$ & $\begin{array}{l}\text { Total } \\
\text { biogas } \\
\text { produced } \\
\left(10^{-3} \mathrm{~m}^{3} /\right. \\
\text { kg TSfed) }\end{array}$ & $\begin{array}{l}\text { Total biogas produced } \\
\text { in co-digestion with } \\
\text { poultry dropping } \\
\left(10^{-3} \mathrm{~m}^{3} / \mathrm{kg} \text { TSfed }\right)\end{array}$ \\
\hline UPH & 0 & 0 & 1119.54 & 1152.47 \\
\hline $\mathrm{pH}_{70,70}$ & 70 & 70 & 1506.02 & 3600.90 \\
\hline $\mathrm{pH}_{80,70}$ & 80 & 70 & 1819.89 & 3903.15 \\
\hline $\mathrm{pH}_{90,60}$ & 90 & 60 & 1801.07 & 3495.67 \\
\hline $\mathrm{PH}_{100,60}$ & 100 & 60 & 1692.12 & 3612.21 \\
\hline $\mathrm{PH}_{110,60}$ & 110 & 60 & 1526.03 & 3562.05 \\
\hline $\mathrm{PH}_{120,60}$ & 120 & 60 & 1552.31 & 3434.31 \\
\hline $\mathrm{PH}_{130,50}$ & 130 & 50 & 1435.21 & 3209.43 \\
\hline $\mathrm{PH}_{140,70}$ & 140 & 70 & 1223.21 & 3375.12 \\
\hline $\mathrm{PH}_{150,50}$ & 150 & 50 & 1323.04 & 3509.12 \\
\hline $\mathrm{PH}_{160,70}$ & 160 & 70 & 1109.21 & 3451.21 \\
\hline $\mathrm{PH} 1_{70,50}$ & 170 & 50 & 1200.21 & 3112.13 \\
\hline $\mathrm{PH}_{180,50}$ & 180 & 50 & 1119.21 & 3167.21 \\
\hline $\mathrm{PH}_{190,60}$ & 190 & 60 & 1081.02 & 3203.14 \\
\hline $\mathrm{PH}_{200,50}$ & 200 & 50 & 1021.23 & 34.12 .41 \\
\hline
\end{tabular}

Note: $\mathrm{PH}=$ Peanut hull; $\mathrm{UPH}=$ Untreated peanut hull.

Biogas generation commenced on the 2nd day in the thermoalkaline pretreated experiment and between the 4th and 6th days in the untreated experiment. In both cases, production continued progressively till between the 19th and 22nd days when reduction in volume was observed and remained till end of the digestions as shown in Fig. 2. From the optimization study, the most desirable actual/experimental biogas yields were $3339.2010^{-3} \mathrm{~m}^{3} / \mathrm{kg}$ TSfed and $1130.2010^{-3} \mathrm{~m}^{3} / \mathrm{kg}$ TSfed with desirability values of 97.5 and $95 \%$ respectively for the pretreated and untreated samples (Table 3). There was an observed 66.15\% higher experimental biogas yield in the thermo-alkaline pretreated over the untreated experiment. As revealed by Gas chromatography, the $\mathrm{CH}_{4}$ and $\mathrm{CO}_{2}$ content of biogas generated in the two experiments were $65.5 \pm 1.5 \% ; 26 \pm 1 \%$ and $53 \pm 1 \% ; 26 \pm 2 \%$ respectively.

\subsection{Microbial composition}

Aerobes, anaerobes and methanogens were all isolated and identified during the anaerobic digestion of the substrates in this study. The aerobes that were isolated include Bacillus pantothenticus, Bacillus licheniformis, Bacillus stearothermophilus, Serratia ficaria, Serratia plymuthica and Proteus vulgaris. Anaerobes that were implicated include Clostridium clostridioforme, Fusobacterium mortiferum and Porphyromonas assacharolyticum while the methanogen are species of Methanococcus, Methanosarcinae and Methanosaeta. The highest count for aerobic bacteria was $2.6 \times 10^{11} \mathrm{cfu} / \mathrm{mL}$ recorded by Bacillus licheniformis in the third week while the lowest $\left(0.1 \times 10^{8} \mathrm{cfu} / \mathrm{mL}\right)$ was recorded for Proteus vulgaris in the sixth week. The highest fungal count of $1.5 \times 10^{8} \mathrm{cfu} / \mathrm{mL}$ was recorded for Aspergillus niger in the third week while the lowest $\left(0.1 \times 10^{4} \mathrm{cfu} / \mathrm{mL}\right)$ was recorded for Mucor in the sixth week. For anaerobes, the highest count of $1.9 \times 10^{11} \mathrm{cfu} / \mathrm{mL}$ was recorded for Clostridium spp. in the sixth week while the lowest $\left(0.3 \times 10^{6} \mathrm{cfu} / \mathrm{mL}\right)$ was recorded for Porphyromonas assacharolytica in the second week. The highest count of methanogens $\left(2.1 \times 10^{12} \mathrm{cfu} / \mathrm{mL}\right)$ was obtained in the sixth week while the lowest count of $0.9 \times 10^{1}{ }^{\circ} \mathrm{Cfu} / \mathrm{mL}$ was obtained in the third week.

Table 4 shows the results of the test of significance and ANOVA for the second-order response surface model for all regression coefficients. As shown in the optimization experimental data in both set ups, all the large F-values have low corresponding pvalues which implies significance $(p<0.05)$ for some of the model terms. For example, the F-values of 2.45 and 3.44 for the models in both studies having corresponding p-values of 0.0126 and 0.0038 implies that both models are significant. In the pretreated experiment, model terms $X, Y, Z, V W, V X, W X, W Z$ and $W^{2}$ were the most significant $(p<0.05)$ while the most significant terms for the untreated experiment were $W, V Y, W X, W Y, X Z$ and $W^{2}$. In checking the 'goodness of fit' of the models, the coefficient of determination $\left(\mathrm{R}^{2}\right)$ was used and the F-values 12.57 and 10.92 with corresponding p-values of 0.0555 and 0.1125 implies non significance respectively for both experiments hence, the fits are good.

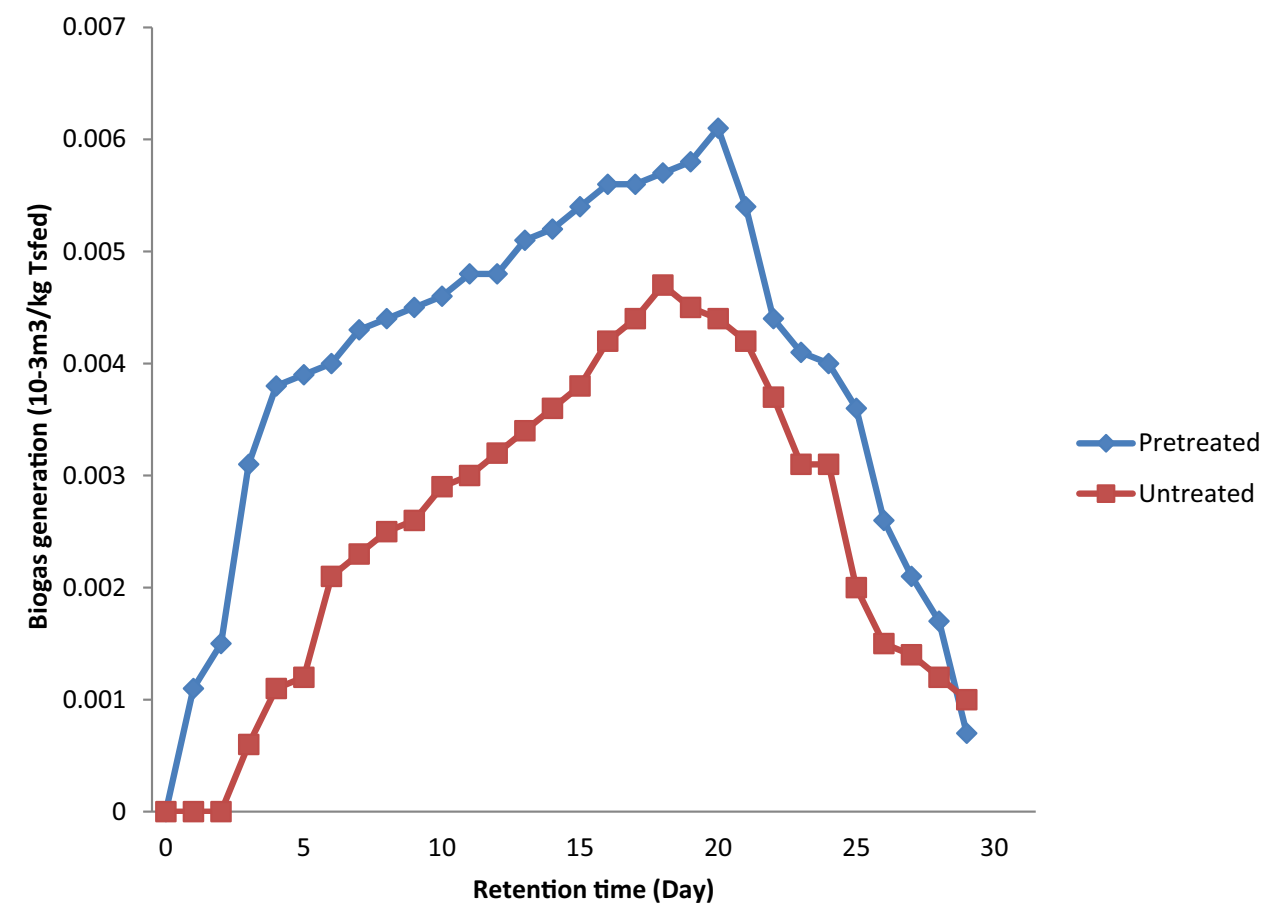

Fig. 2. Daily biogas generation in the anaerobic co-digestion of the two samples of Arachis hypogaea + poultry dropping. 
Table 3

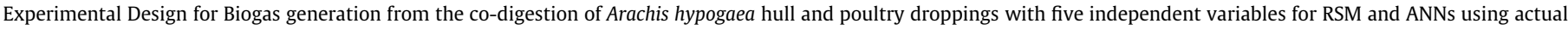
values.

\begin{tabular}{|c|c|c|c|c|c|c|c|c|c|c|c|}
\hline \multirow[t]{2}{*}{ Run } & \multicolumn{5}{|c|}{ Independent Factors } & \multicolumn{3}{|c|}{ Pretreated A. hypogaea hull + Poultry droppings } & \multicolumn{3}{|c|}{ Untreated A. hypogaea hull + Poultry droppings } \\
\hline & V & $W$ & $X$ & $Y$ & $Z$ & $\begin{array}{l}\text { Actual biogas } \\
\text { yield }\left(10^{-3} \mathrm{~m}^{3} /\right. \\
\text { kg TSfed })\end{array}$ & $\begin{array}{l}\text { RSM Predicted } \\
\text { biogas yield } \\
\left(10^{-3} \mathrm{~m}^{3} / \mathrm{kg} \text { TSfed }\right)\end{array}$ & $\begin{array}{l}\text { ANNs Predicted } \\
\text { biogas yield } \\
\left(10^{-3} \mathrm{~m}^{3} / \mathrm{kg} \text { TSfed }\right)\end{array}$ & $\begin{array}{l}\text { Actual biogas } \\
\text { yield }\left(10^{-3} \mathrm{~m}^{3} /\right. \\
\mathrm{kg} \text { TSfed })\end{array}$ & $\begin{array}{l}\text { RSM Predicted } \\
\text { biogas yield } \\
\left(10^{-3} \mathrm{~m}^{3} / \mathrm{kg} \text { TSfed }\right)\end{array}$ & $\begin{array}{l}\text { ANNs Predicted } \\
\text { biogas yield } \\
\left(10^{-3} \mathrm{~m}^{3} / \mathrm{kg} \text { TSfed }\right)\end{array}$ \\
\hline 1 & 32.00 & 7.62 & 30.00 & 12.00 & 10.00 & 3339.2 & 3903.15 & 3338.3 & 1130.2 & 1152.47 & 1123.4 \\
\hline 2 & 39.98 & 7.99 & 30.00 & 12.00 & 11.92 & 3000.9 & 3887.25 & 3702.3 & 1165.9 & 1162.35 & 1182.9 \\
\hline 3 & 39.97 & 8.00 & 29.99 & 11.77 & 11.84 & 3665.1 & 3857.38 & 3666.4 & 1131.3 & 1141.41 & 1100.8 \\
\hline 4 & 39.84 & 8.00 & 29.97 & 11.88 & 12.00 & 3873.3 & 3881.06 & 3872.5 & 1154.1 & 1203.28 & 1101.1 \\
\hline 5 & 39.96 & 8.00 & 30.00 & 12.00 & 11.58 & 3600.1 & 3843.66 & 3699.7 & 1100.1 & 1143.60 & 1138.4 \\
\hline 6 & 40.00 & 8.00 & 30.00 & 12.00 & 11.43 & 3723.1 & 3824.98 & 3712.4 & 1215.4 & 1251.31 & 1135.4 \\
\hline 7 & 40.00 & 7.97 & 30.00 & 11.85 & 11.54 & 3884.2 & 3806.01 & 3883.9 & 1110.5 & 1122.22 & 1119.7 \\
\hline 8 & 39.99 & 7.93 & 29.99 & 11.64 & 12.00 & 3535.9 & 3808.08 & 3554.9 & 1184.2 & 1222.52 & 1126.3 \\
\hline 9 & 40.00 & 8.00 & 30.00 & 11.46 & 11.27 & 3763.3 & 3753.10 & 3767.5 & 1103.5 & 1119.11 & 1117.4 \\
\hline 10 & 39.93 & 7.86 & 30.00 & 12.00 & 11.79 & 3751.1 & 3758.88 & 3746.0 & 1114.2 & 1125.26 & 1115.9 \\
\hline 11 & 40.00 & 8.00 & 29.60 & 10.49 & 12.00 & 3507.1 & 3721.13 & 3507.7 & 1147.5 & 1159.25 & 1127.6 \\
\hline 12 & 39.57 & 7.88 & 30.00 & 11.97 & 12.00 & 3581.0 & 3786.21 & 3589.6 & 1121.1 & 1150.22 & 1139.8 \\
\hline 13 & 40.00 & 7.92 & 30.00 & 12.00 & 10.58 & 3591.6 & 3653.46 & 3590.1 & 1162.6 & 1204.14 & 1186.6 \\
\hline 14 & 39.01 & 7.98 & 30.00 & 11.90 & 12.00 & 4000.0 & 4132.28 & 3993.6 & 1177.6 & 1161.05 & 1156.9 \\
\hline 15 & 40.00 & 8.00 & 29.97 & 12.00 & 9.98 & 3701.2 & 3634.73 & 3701.7 & 1108.2 & 1188.62 & 1165.5 \\
\hline 16 & 38.75 & 8.00 & 30.00 & 11.12 & 12.00 & 3511.9 & 3756.92 & 3502.2 & 1201.1 & 1220.14 & 1111.4 \\
\hline 17 & 40.00 & 7.56 & 29.01 & 12.00 & 12.00 & 3602.5 & 3493.71 & 3586.7 & 1155.8 & 1161.82 & 1156.6 \\
\hline 18 & 39.46 & 7.74 & 30.00 & 10.81 & 12.00 & 3432.0 & 3568.03 & 3434.5 & 1162.6 & 1236.53 & 1144.3 \\
\hline 19 & 39.74 & 8.00 & 30.00 & 12.00 & 8.87 & 3227.3 & 3491.05 & 3219.5 & 1109.4 & 1123.42 & 1117.1 \\
\hline 20 & 40.00 & 7.91 & 30.00 & 10.64 & 9.69 & 3500.9 & 3433.42 & 3402.0 & 1100.4 & 1122.71 & 1118.0 \\
\hline 21 & 39.99 & 7.72 & 30.00 & 9.11 & 12.00 & 3200.1 & 3415.48 & 3286.7 & 1212.3 & 1242.01 & 1225.8 \\
\hline 22 & 40.00 & 7.27 & 29.21 & 12.00 & 12.00 & 3297.2 & 3322.08 & 3200.7 & 1120.3 & 1141.28 & 1124.5 \\
\hline 23 & 39.04 & 7.46 & 29.53 & 12.00 & 12.00 & 3256.1 & 3433.61 & 3255.3 & 1109.2 & 1207.31 & 1200.1 \\
\hline 24 & 40.00 & 8.00 & 29.12 & 11.99 & 7.27 & 2942.1 & 3248.76 & 3086.7 & 1127.3 & 1167.43 & 1129.3 \\
\hline 25 & 40.00 & 7.02 & 30.00 & 12.00 & 11.92 & 3298.1 & 3224.96 & 3204.1 & 1192.1 & 1194.11 & 1190.5 \\
\hline 26 & 40.00 & 6.85 & 30.00 & 11.75 & 12.00 & 3050.1 & 3126.99 & 3037.0 & 1080.1 & 1111.14 & 1105.9 \\
\hline 27 & 40.00 & 6.83 & 30.00 & 11.57 & 11.93 & 3009.0 & 3101.96 & 3014.7 & 1199.5 & 1195.01 & 1167.3 \\
\hline 28 & 40.00 & 8.00 & 30.00 & 11.99 & 4.96 & 2910.0 & 3090.30 & 2911.2 & 1103.1 & 1198.07 & 1105.4 \\
\hline 29 & 40.00 & 8.00 & 30.00 & 6.77 & 8.70 & 3000.0 & 3055.35 & 2986.7 & 1150.5 & 1153.31 & 1156.7 \\
\hline 30 & 40.00 & 8.00 & 21.73 & 9.77 & 12.00 & 2856.0 & 3052.25 & 2857.0 & 1156.6 & 1172.01 & 1166.6 \\
\hline 31 & 40.00 & 8.00 & 30.00 & 11.46 & 11.27 & 3751.1 & 3758.88 & 3889.6 & 1170.1 & 1177.51 & 1162.9 \\
\hline 32 & 39.93 & 7.86 & 30.00 & 12.00 & 11.79 & 3507.1 & 3721.13 & 3590.1 & 1077.1 & 1110.21 & 1114.4 \\
\hline 33 & 40.00 & 8.00 & 29.60 & 10.49 & 12.00 & 3581.0 & 3786.21 & 3593.6 & 1120.4 & 1141.11 & 1138.2 \\
\hline 34 & 39.57 & 7.88 & 30.00 & 11.97 & 12.00 & 3591.6 & 3653.46 & 3601.7 & 1119.5 & 1141.10 & 1109.2 \\
\hline 35 & 40.00 & 7.92 & 30.00 & 12.00 & 10.58 & 4000.0 & 3832.28 & 3802.2 & 1155.6 & 1172.55 & 1135.8 \\
\hline 36 & 39.01 & 7.98 & 30.00 & 11.90 & 12.00 & 3501.2 & 3634.73 & 3586.7 & 1137.5 & 1151.43 & 1141.1 \\
\hline 37 & 40.00 & 8.00 & 29.97 & 12.00 & 9.98 & 3511.9 & 3756.92 & 3534.5 & 1238.5 & 1253.16 & 1144.4 \\
\hline 38 & 38.75 & 8.00 & 30.00 & 11.12 & 12.00 & 3302.5 & 3493.71 & 3319.5 & 1157.3 & 1102.43 & 1194.6 \\
\hline 39 & 40.00 & 7.56 & 29.01 & 12.00 & 12.00 & 3232.0 & 3568.03 & 3502.0 & 1102.1 & 1108.05 & 1106.4 \\
\hline 40 & 39.46 & 7.74 & 30.00 & 10.81 & 12.00 & 3427.3 & 3491.05 & 3486.7 & 1102.4 & 1119.09 & 1114.2 \\
\hline 41 & 39.74 & 8.00 & 30.00 & 12.00 & 8.87 & 3100.9 & 3433.42 & 3200.7 & 1110.1 & 1118.14 & 1114.7 \\
\hline 42 & 40.00 & 7.91 & 30.00 & 10.64 & 9.69 & 3200.1 & 3415.48 & 3255.3 & 1102.5 & 1124.12 & 1122.6 \\
\hline 43 & 39.99 & 7.72 & 30.00 & 9.11 & 12.00 & 3297.2 & 3322.08 & 3286.7 & 1199.9 & 1146.63 & 1109.3 \\
\hline 44 & 40.00 & 7.27 & 29.21 & 12.00 & 12.00 & 2356.1 & 3433.61 & 3204.1 & 1150.2 & 1173.22 & 1160.5 \\
\hline 45 & 39.04 & 7.46 & 29.53 & 12.00 & 12.00 & 2992.1 & 3248.76 & 3237.0 & 1150.4 & 1156.64 & 1156.7 \\
\hline 46 & 40.00 & 8.00 & 29.12 & 11.99 & 7.27 & 3098.1 & 3224.96 & 3214.7 & 1138.3 & 1143.33 & 1136.8 \\
\hline 47 & 40.00 & 7.02 & 30.00 & 12.00 & 11.92 & 3150.1 & 3126.99 & 3111.2 & 1151.7 & 1163.25 & 1155.4 \\
\hline 48 & 40.00 & 6.85 & 30.00 & 11.75 & 12.00 & 3109.0 & 3101.96 & 2986.7 & 1159.6 & 1166.18 & 1154.7 \\
\hline 49 & 40.00 & 6.83 & 30.00 & 11.57 & 11.93 & 2990.0 & 3090.30 & 2857.0 & 1122.4 & 1161.45 & 1160.2 \\
\hline 50 & 40.00 & 8.00 & 30.00 & 11.99 & 4.96 & 3063.1 & 3012.30 & 3008.4 & 1152.2 & 1155.61 & 1148.5 \\
\hline
\end{tabular}

$\mathrm{V}=$ Temperature; $\mathrm{W}=\mathrm{pH} ; \mathrm{X}=$ Retention time; $\mathrm{Y}=$ Total solids: $\mathrm{Z}=$ Volatile solids.

The 'Adequate Precision' was used to check if the models could be adequately used for the prediction and the 11.627 and 9.413 values obtained indicates adequate modeling. The regression equation below shows the relationship between all the five variables (in coded form) used in the modeling of the thermo-alkaline pretreated experiment and the biogas yield $(B)$ :

$$
\begin{aligned}
B= & 1662.02-65.93_{V}+99.71_{W}+117.08_{X}+162.94_{Y} \\
& -63.17 Z-154.68_{V W}-132.15_{V X}-118.16_{V Y}+147.50_{V Z} \\
& +127.53_{W X}+182.63_{W Y}-147.86_{W Z}+142.30_{X Y} \\
& -170.05_{X Z}-160.59_{Y Z}+48.78_{V^{2}}+62.53_{W^{2}}+65.81_{X^{2}} \\
& -63.33_{Y^{2}}+51.80_{Z^{2}}
\end{aligned}
$$

where $B=$ Biogas yield $\left(10^{-3} \mathrm{~m}^{3} / \mathrm{kg}\right.$ TSfed $)$.
In order to obtain the optimal value for each independent variable used in the optimization, the above regression equation was solved and the resulting values are: $V=32.00^{\circ} \mathrm{C}, W=7.62$, $X=30.00$ day, $Y=12.00 \mathrm{~g} / \mathrm{kg}$ and $Z=10.00 \mathrm{~g} / \mathrm{kg}$. When these values were taken into account, the predicted biogas yield for RSM in the thermo-alkaline pretreated experiment was $3903.1510^{-3} \mathrm{~m}^{3}$ / $\mathrm{kg}$ TSfed and $3338.3010^{-3} \mathrm{~m}^{3} / \mathrm{kg}$ TSfed for ANNs. For the experiment without pretreatment, the RSM predicted yield was $1152.4710^{-3} \mathrm{~m}^{3} / \mathrm{kg}$ TSfed while that of ANNs was $1123.4010^{-3} \mathrm{~m}^{3} / \mathrm{kg}$ TSfed. Overall, there was $70.47 \%$ biogas yield increase in the experiment with thermo-alkaline pretreatment over that of untreated. Verification of the model's prediction was done by applying the predicted values to three replicate for both pretreated and untreated experiments and the average biogas yield of 3871.43 and $1121.1410^{-3} \mathrm{~m}^{3} / \mathrm{kg}$ TSfed were obtained respec- 
Table 4

Test of significance and Analysis of variance (ANOVA) for all regression coefficient terms for biogas generation from Arachis hypogaea hull and poultry droppings.

\begin{tabular}{|c|c|c|c|c|c|c|c|c|c|}
\hline \multirow[t]{2}{*}{ Source } & \multirow[t]{2}{*}{ df } & \multicolumn{4}{|c|}{ Pretreated A. hypogaea hull + Poultry droppings } & \multicolumn{4}{|c|}{ Untreated A. hypogaea hull + Poultry droppings } \\
\hline & & SS & MS & F-value & P-value & SS & MS & F-value & P-value \\
\hline V & 1 & 8907 & 8907 & 2.48 & 0.1497 & 4132 & 4132 & 2.04 & 0.1530 \\
\hline W & 1 & 163.1 & 163.1 & 4.543 & 0.9477 & 7330 & 7330 & 1.98 & 0.0323 \\
\hline$X$ & 1 & 3.885 & 3.885 & 10.82 & 0.0094 & 2.911 & 2.911 & 4.13 & 0.2704 \\
\hline$Y$ & 1 & 6.859 & 6.859 & 19.11 & 0.0018 & 4.275 & 4.275 & 14.12 & 0.5252 \\
\hline$Z$ & 1 & 2.871 & 2.871 & 8.00 & 0.0198 & 5109 & 5109 & 2.00 & 0.1312 \\
\hline$V^{*} W$ & 1 & 1.607 & 1.607 & 4.48 & 0.0235 & 4028 & 4028 & 5.06 & 0.0721 \\
\hline$V^{*} X$ & 1 & 1.164 & 1.164 & 3.24 & 0.0053 & 1.394 & 1.394 & 2.42 & 0.1461 \\
\hline$V^{*} Y$ & 1 & 1116 & 1116 & 0.031 & 0.8640 & 0.098 & 0.098 & 1.44 & 0.0111 \\
\hline$V^{*} Z$ & 1 & 1480 & 1480 & 0.41 & 0.5368 & 2.687 & 2.687 & 1.42 & 0.2412 \\
\hline$W^{*} X$ & 1 & 1.637 & 1.637 & 4.56 & 0.0125 & 3.628 & 3.628 & 3.83 & 0.0276 \\
\hline$W^{*} Y$ & 1 & 8177 & 8177 & 2.28 & 0.1655 & 6632 & 6632 & 6.47 & 0.0726 \\
\hline$W^{*} Z$ & 1 & 5.309 & 5.309 & 14.79 & 0.0039 & 4890 & 4890 & 1.13 & 0.1635 \\
\hline$X^{*} Y$ & 1 & 8356 & 8356 & 2.33 & 0.1614 & 2.343 & 2.343 & 3.45 & 0.0212 \\
\hline$X^{*} Z$ & 1 & 1381 & 1381 & 0.38 & 0.5504 & 5270 & 5270 & 3.20 & 0.0207 \\
\hline$Y^{*} Z$ & 1 & 1.536 & 1.536 & 4.28 & 0.0685 & 4.232 & 4.232 & 3.42 & 0.0763 \\
\hline$V^{2}$ & 1 & 1645 & 1645 & 0.46 & 0.5155 & 5.263 & 5.263 & 5.09 & 0.2187 \\
\hline$W^{2}$ & 1 & 1.688 & 1.688 & 4.70 & 0.0282 & 1.048 & 1.048 & 2.33 & 0.0437 \\
\hline$X^{2}$ & 1 & 9176 & 9176 & 0.26 & 0.6253 & 1.128 & 1.128 & 1.75 & 0.2925 \\
\hline$Y^{2}$ & 1 & 7238 & 7238 & 0.20 & 0.6640 & 2.562 & 2.562 & 1.46 & 0.3319 \\
\hline$Z^{2}$ & 1 & 7046 & 7046 & 1.96 & 0.1948 & 1.493 & 1.493 & 4.14 & 0.0517 \\
\hline Model & 20 & 3.060 & 2.724 & 2.45 & 0.0126 & 3.540 & 1.272 & 3.44 & 0.0038 \\
\hline Residual & 9 & 3.231 & 82369 & & & 5.816 & 92993 & & \\
\hline Lack of Fit & 6 & 2.720 & 1.472 & 12.57 & 0.0555 & 7.115 & 1.315 & 10.92 & 0.1125 \\
\hline Pure Error & 3 & 1.243 & 139.04 & & & 1.571 & 144.11 & & \\
\hline R-Squared & & 0.9045 & & & & 0.8864 & & & \\
\hline Adequate Precision & & 11.627 & & & & 9.413 & & & \\
\hline
\end{tabular}

$\mathrm{df}=$ Degree of freedom; $\mathrm{SS}=$ Sum of square; MS = Mean square.

tively. Further representation of Eq. (3) is shown in forms of 3-D response surface graphs for both RSM and ANNs (Fig. S3 a-j).

\subsection{Mass balances}

The mass balances for both the thermo-alkaline pretreated and untreated $A$. hypogaea hull + poultry dropping are shown in Table 5. The volatile solids (VS) consumption was evaluated by using " $A$. hypogaea + poultry dropping" as the input variable while the trio of "methane", "carbon dioxide" and the resulting "anaerobic digestate" were considered as the output variables. There was $47.11 \%$ higher VS removal/consumption in the thermo-alkaline pretreated experiment over the corresponding value removal in the untreated experiment. Similarly, there was $54.05 \%$ higher mass balance in the pretreated experiment than the untreated. Results of the thermoalkaline pretreatment application showed high reduction/ solubilization of all the evaluated basic structural components as well as the enhancement of high soluble sugar yield from the pretreated biomass. Previously, thermo-alkaline pretreatment have been applied to grass silage and sunflower stalk in which high lignin solubilization was achieved (Xie et al., 2011; Monlau et al., 2015). Another indication of lignin solubilization is the high yield/production of phenolic compounds and the $15.27 \mathrm{mg} \mathrm{L}^{-1}$ reported in the thermo-alkaline pretreated $A$. hypogaea hull in this study further confirmed pronounced structural breakdown. Dahunsi et al. (2017b) reported such trend with the application of alkaline pretreatment to sunflower stock. The $\mathrm{pH}$ values of between 6.5 and 8 is replete in literature as the ideal range for efficiency of anaerobic microorganisms especially the archaea (Zonta et al., 2013; Dahunsi et al., 2016a,b). The pH values obtained in this study therefore agree with standard range reported in literature and this contributed to the success of the anaerobic system. Maintenance of suitable $\mathrm{pH}$ in $\mathrm{AD}$ systems is therefore germane to ensuring adequate and rich microbial population and activities beside enhancing the overall success of the systems (Zahedi et al., 2016). Mesophilic temperature that was maintained throughout the
Table 5

Stoichiometry and mass balance for one ton of substrate (Arachis hypogaea hull + Poultry droppings) from the anaerobic digestion experiments.

\begin{tabular}{lll}
\hline Parameter & $\begin{array}{l}\text { Pretreated } A . \\
\text { hypogaea hull } \\
\text { + Poultry } \\
\text { droppings }\end{array}$ & $\begin{array}{l}\text { Untreated } A . \\
\text { hypogaea hull } \\
\text { + Poultry } \\
\text { droppings }\end{array}$ \\
\hline $\begin{array}{l}\text { Input } \\
\text { A. hypogaea hulls + Poultry droppings }(\mathrm{kg})\end{array}$ & 1000 & 1000 \\
Volatile solids $(\mathrm{VS})(\mathrm{kg})$ & 964 & 995 \\
Output & & \\
Methane $\left(\mathrm{CH}_{4}\right)(\%)$ & 65.5 & 53 \\
Carbon dioxide $\left(\mathrm{CO}_{2}\right)(\%)$ & 26 & 26 \\
Digestate $(\mathrm{kg} \mathrm{VS})$ & 468 & 724 \\
Sum & 559.5 & 803 \\
*Mass balance & 42 & 19.3 \\
\% Volatile solids (VS) removal & 51.5 & 27.24 \\
\hline
\end{tabular}

*= (Input-output)/input (\%).

digestion process equally ensured adequate growth and proper synergy between acid-producing and methane-producing bacteria and such has been previously reported in AD system (Jain et al., 2015).

Physico-chemically, A. hypogaea hull was revealed to be rich in important mineral elements and nutrients necessary for microbial survival, proliferation and adequate metabolism while in a fermentation medium. Also, the thermo-alkaline pretreated sample was shown to be enormously richer than the untreated in terms of nutrients composition which was brought about as a result of the pretreatment as it enhanced the breakdown of the structural materials thereby yielding much nutrient that were earlier locked up in the biomass tissues. Another positive effect of the thermoalkaline pretreatment was the increased $\mathrm{C} / \mathrm{N}$ ratio of 16 recorded for the treated substrate and this agrees very closely with the 17 reported by Degueurce et al. (2016) by digesting spent cow beddings. Likewise, values of elements such as nitrogen, phosphorus, potassium, magnesium, manganese, iron, zinc, aluminium and 
Table 6

Energy and economic evaluation for the anaerobic digestion of Arachis hypogaea hull + Poultry droppings.

\begin{tabular}{|c|c|c|}
\hline Energy parameters & $\begin{array}{l}\text { Pretreated A. hypogaea + } \\
\text { Poultry droppings }\end{array}$ & $\begin{array}{l}\text { Untreated A. hypogaea + } \\
\text { Poultry droppings }\end{array}$ \\
\hline Produced electrical and thermal energy from combined heat and power (CHP) & 1127 & 531 \\
\hline Produced thermal energy ( $\left.\mathrm{kWh} \mathrm{t}^{-1} \mathrm{TS}\right)$ & 1211 & 450 \\
\hline Produced electrical energy ( $\left.\mathrm{kWh} \mathrm{t}^{-1} \mathrm{TS}\right)$ & 684 & 381 \\
\hline \multicolumn{3}{|l|}{ Thermal balance } \\
\hline *Thermal energy gain $\left(\mathrm{kWh} \mathrm{t}^{-1} \mathrm{TS}\right)$ & 761 & - \\
\hline Thermal energy requirement ( $\left.\mathrm{kWh} \mathrm{t}^{-1} \mathrm{TS}\right)$ & 1173 & - \\
\hline Thermal energy requirement with $80 \%$ of heat recovery (kWh t ${ }^{-1} \mathrm{TS}$ ) & 255 & - \\
\hline${ }^{\#}$ Net thermal energy $\left(\mathrm{kWh} \mathrm{t}^{-1} \mathrm{TS}\right)$ & -412 & - \\
\hline Net thermal energy with $80 \%$ of heat recovery (kWh t ${ }^{-1} \mathrm{TS}$ ) & 506 & - \\
\hline \multicolumn{3}{|l|}{ Electrical balance } \\
\hline${ }^{\$}$ Electrical energy gain & 303 & - \\
\hline Energy for mixing during pre-treatment & - & - \\
\hline Net electrical energy & 303 & \\
\hline \multicolumn{3}{|l|}{ Economic evaluation } \\
\hline Cost of $\mathrm{NaOH}\left(\mathrm{et}^{-1} \mathrm{TS}\right)$ & & \\
\hline
\end{tabular}

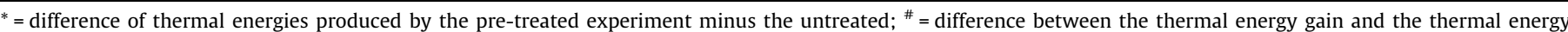
requirement for the thermo-alkaline pretreatment; ${ }^{\$}=$ difference of electricity energies produced by pretreated experiment minus the untreated.

copper increased in the two anaerobic digestates obtained after digestion as against their initial lower values. However, reduction in value was observed for total carbon and calcium in the digestates and this is attributed to uptake of these elements for microbial metabolism and as building blocks for cell wall synthesis. There were no recorded inhibition by nitrogen and its compounds during the $\mathrm{AD}$ processes as moderate Nitrogen contents were recorded for A. hypogaea hull and this is similar to the results obtained from the AD of food wastes and different spent animal beddings (Riggio et al., 2017).

The digestates are highly useful as biofertilizers due to their richness in nutrients coupled with great potentials to increase both the microbial and nutrient status of soil especially nutrientdepleted ones when applied. Application of these digestates as biofertilizer could equally enhance plant growth and general wellbeing especially in Sub-Saharan Africa and other regions bedevilled with issues ranging from soil nutrient depletion, toxicity to soil microorganisms to leaching of nutrients and pollution is on the increase due to over-dependence on the use of chemical fertilizers. In this regard, a number of studies have documented the suitability of anaerobic digestates as substitutes for inorganic chemical fertilizers in different cropping systems (Alfa et al., 2014a; Dahunsi et al., 2016a,b; Westphal et al., 2016). Another major characteristic of the digestates was COD reduction and the higher reduction in the thermo-alkaline pretreated experiment is due to malleability of the pretreated substrates to efficient microbial/enzymatic degradation of organic matter due to delignification.

The type and concentrations of VFA's are obtained in this study is similar to those earlier reported (Riggio et al., 2017). Also, both acetogenesis and methanogenesis stages of the $\mathrm{AD}$ were pronounced and this is attributed to the high population and diversity of bacterial species inoculated in the system especially the dominant genera Clostridium which was brought about by the thermo-alkaline pretreatment application prior to digestion. These bacterial groups have been reported to be efficient in amino-acids degradation to produce intermediate acids such as acetic and propionic acids and ammonia as end-products (Degueurce et al., 2016). The maintenance of neutral $\mathrm{pH}$ in this study was as a result of the buffering activities of ammonia and this in turn ensured the AD stability beside high methane yield especially in the thermoalkaline pretreated experiment. Considering the quantities of biogas produced in this study, application of thermo-alkaline pretreatment was very efficient as $70.47 \%$ higher biogas yield was obtained over the untreated and this is far higher than the $26.5 \%$ increase reported when same pretreatment was applied in the
AD of Carica papayas fruit peels (Dahunsi et al., 2017c). To this end, pretreatment (especially combination of methods) of lignocellulosic biomasses has been severally recommended in order to facilitate substrate degradation, AD microbial activities and higher biogas yield (Li et al., 2015; Dahunsi et al., 2016a,b, 2017a,b,c,d).

The parameters for validating the significance of the regression models i.e. the F-values with their corresponding low p-values and the $\mathrm{R}^{2}$ values reveal significance. Similarly, an 'adequate precision' value of $\geq 4$ is generally acceptable for the good fitting of a model and the 11.627 and 9.413 values reported in the optimizations in this study implies good fit and suitability of the models which were equally validated by all the significant model terms with $\mathrm{p}<0.05$. The lack-of-fit terms of 0.0555 and 0.1125 for both studies were not significant and further validated the model's accuracy. The curvature nature of all the RSMs 3-D plots show low interactions among $V, W, X, Y$ and $Z$ while pronounced interactions were shown by the ANNs plots which is an indication that ANNs is a better model in terms of variable interactions. Such assertions have been documented by previous studies (Dahunsi et al., 2017b,c). In estimating the accuracy and predictive abilities of both models in optimization of the biogas data generated in this study, parameters such as the mean squared error (RSME), $\mathrm{R}^{2}$ values and the predicted biogas yield were employed. The RSMEs reported for RSM were 139.04 and 144.11 which were higher than those of ANN (38.42 and 44.11). On the other hand, the $\mathrm{R}^{2}$ values for RSM were 0.9045 and $0.8864 \%$ which were lower than those of ANNs' (0.9994 and $0.9775 \%)$. In terms of biogas yield prediction, RSMs was better while ANNs' accuracy was higher determined by the $\mathrm{R}^{2}$ value and error reading and is therefore the appropriate model for optimization of data from the $\mathrm{AD}$ of A. hypogaea hull + poultry droppings.

The results of mass balance showed higher VS consumption in the thermo-alkaline pretreated substrate than the untreated caused by pronounced microbial activities in substrate degradation and subsequent bioconversion of organic matter to biogas. In order to fully assess the energy balance and economic feasibility of thermo-alkaline pretreatment for $A$. hypogaea hull as carried out in this study (Table 6), the combined heat and power (CHP) system which has become very popular in energy conversion globally was adopted with thermal and electrical efficiencies of 50 and 35\% respectively. The possibility that the profit gained from the sale of the extra thermal and electrical energy will be sufficient to cover the cost of thermal energy and $\mathrm{NaOH}$ used during the pretreatment. In determining the thermal energy required to carry out the thermo-alkaline pretreatment, the energy needed to raise the 
temperature of $35 \mathrm{~g} \mathrm{TS} \mathrm{L}^{-1} A$. hypogaeaa hull mixture from the of $25^{\circ} \mathrm{C}$ to $55^{\circ} \mathrm{C}$ using the water specific heat of $4.18 \mathrm{~kJ} \mathrm{~kg}^{-1}{ }^{\circ} \mathrm{C}^{-1}$ to evaluate the specific heat of the mixture of $A$. hypogaea hull and water neglecting heat loss was determined according to earlier documented studies (Zupancic and Ros, 2003). In the long run, the $761 \mathrm{kWh} \mathrm{t}^{-1}$ TS thermal energy gain at a solid loading of $35 \mathrm{~g} \mathrm{TS} \mathrm{L}^{-1}$ was lower than the $1173 \mathrm{kWh} \mathrm{t}^{-1}$ TS heat energy needed for the thermo-alkaline pretreatment. However, the use of heat exchanger in the heating of the digesters or for pretreatment is a veritable way of recovering up to $80 \%$ of the heat energy and this has been earlier advocated (Dahunsi et al., 2017b,d). Another way of assessing the economic feasibility of thermoalkaline pretreatment is by full integration of thermal energy.

For the electrical energy requirements for the thermo-alkaline pretreatment, priority was given only to the electric energy used for the substrate mixing while the energy used for mechanical grinding was neglected as same was used in the experiment without thermo-alkaline pretreatment (Dahunsi et al., 2017b). The estimated net electrical energy from the thermo-alkaline pretreatment of A. hypogaea hull in this study at a solid loading of $35 \mathrm{~g} \mathrm{TS} \mathrm{L}^{-1}$ was $303 \mathrm{kWh} \mathrm{t}^{-1}$ TS which can either be directly injected into the national energy grid or sold at a particular rate in order to get additional economic benefit. The $412 €$ ton $^{-1}$ European Union price of $\mathrm{NaOH}$ was used to account for its economic assessment.

\section{Conclusion}

As shown in this study, the mixture of A. hypogaea hull and poultry droppings was very rich nutrients and minerals elements making it suitable candidate for biogas and digestate biofertilizer production. It was equally revealed that the use of thermoalkaline pretreatments prior to anaerobic digestion led to higher biogas production. The study also revealed that ANNs has higher precision for prediction of biogas generation from the mixture. As the world moves from a fossil fuel-powered society to a biobased sustainable one, co-digestion of peanut hull with poultry droppings and other energy-yielding substrates is a gateway to solving the crisis.

\section{Competing interest}

The authors declare that they have no competing interest.

\section{Acknowledgements}

Authors are grateful to our Laboratory staffs who assisted in carrying out parts of the work.

\section{Appendix A. Supplementary data}

Supplementary data associated with this article can be found, in the online version, at http://dx.doi.org/10.1016/j.biortech.2017.05. 152.

\section{References}

Abudi, Z.N., Hu, Z., Sun, N., Xiao, B., Rajaa, N., Liu, C., et al., 2016. Batch anaerobic codigestion of OFMSW (organic fraction of municipal solid waste), TWAS (thickened waste activated sludge) and RS (rice straw): Influence of TWAS and RS pretreatment and mixing ratio. Energy 107, 131-140.

Agricultural Marketing and Resource Center (AgMRC), 2015. Iowa State University. Alfa, I.M., Adie, D.B., Igboro, S.B., Oranusi, U.S., Dahunsi, S.O., Akali, D.M., 2014a. Assessment of biofertilizer quality and health implications of anaerobic digestion effluent of cow dung and chicken droppings. Renewable Energy 63, 681-686.

Alfa, I.M., Dahunsi, S.O., Iorhemen, O.T., Okafor, C.C., Ajayi, S.A., 2014b. Comparative evaluation of biogas production from poultry droppings, cow dung and lemon grass. Bioresour. Technol. 157, 270-277.
Anike, F.N., Yusif, M., Isikhuemhen, O.S., 2016. Co-substrating of peanut shells with cornstalks enhances biodegradation by Pleurotus ostreatus. J. Bioremed. Biodegrad. 7, 327.

Appels, L., Degreve, J., Bruggen, B.V., Impe, J.V., Dewil, R., 2010. Influence of low temperature thermal pre-treatment on sludge solubilization, heavy metal release and anaerobic digestion. Bioresour. Technol. 101, 5743-5748.

Ayandiran, T.A., Dahunsi, S.O., 2017. Microbial evaluation and occurrence of antidrug multi-resistant organisms among the indigenous Clarias species in River Oluwa. Nigeria. J. King Saud Univ. - Sci. 29, 96-105.

Carrere, H., Dumas, C., Battimelli, A., Batsone, D.J., Delgenes, J.P., Steyer, J.P., 2010. Pretreatment methods to improve sludge anaerobic degradability: a review. J. Hazard. Mater. 183, 1-15.

Cesarino, I., Araujo, P., Domingues Junior, A.P., Mazzafera, P., 2012. An overview of lignin metabolism and its effect on biomass recalcitrance. Braz. J. Bot. 35, 303311.

Chamchoi, N., Garcia, H., Angelidaki, I., 2011. Methane potential of household waste; batch assays determination. J. Environ. Resour. 33, 13-26.

Costa, A.G., Pinheiro, G.C., Pimheiro, F.G.C., Dos Santos, A.B., Santaella, S.T., Leitao, R. C. 2014. The use of thermochemical pretreatments to improve the anaerobic biodegradability and biochemical methane potential of the sugarcane bagasse. Chem. Eng. J. 248, 363-372.

Dahunsi, S.O., Oranusi, S., Efeovbokhan, V.E., 2017a. Cleaner energy for cleaner production: Modeling and optimization of biogas generation from Carica papayas (Pawpaw) fruit peels. J. Cleaner Prod. 156, 19-29.

Dahunsi, S.O., Oranusi, S., Efeovbokhan, V.E., 2017b. Optimization of pretreatment, process performance, mass and energy balance in the anaerobic digestion of Arachis hypogaea (Peanut) hull. Energy Convers. Manage. 139, 260-275.

Dahunsi, SO, Oranusi, S, Efeovbokhan, VE, 2017c. Bioconversion of Tithonia diversifolia (Mexican sunflower) and poultry droppings for energy generation: optimization, mass and energy balances, and economic benefits. Energy Fuels. http://dx.doi.org/10.1021/acs.energyfuels.7b00148.

Dahunsi, S.O., Oranusi, S., Owolabi, J.B., Efeovbokhan, V.E., 2016a. Comparative biogas generation from fruit peels of Fluted Pumpkin (Telfairia occidentalis) and its optimization. Bioresour. Technol. 221, 517-525.

Dahunsi, S.O., Oranusi, S., Owolabi, J.B., Efeovbokhan, V.E., 2016b. Mesophilic anaerobic co-digestion of poultry droppings and Carica papaya peels: modeling and process parameter optimization study. Bioresour. Technol. 216, 587-600.

Dahunsi, S.O., Oranusi, S., Owolabi, J.B., Efeovbokhan, V.E., 2017d. Synergy of Siam weed (Chromolaena odorata) and poultry manure for energy generation: effects of pretreatment methods, modeling and process optimization. Bioresour. Technol. 225, 409-417.

Dahunsi, S.O., Oranusi, U.S., 2013. Co-digestion of food waste and human excreta for biogas production. Br. Biotechnol. J. 3 (4), 485-499.

Dahunsi, S.O., Owamah, H.I., Ayandiran, T.A., Oranusi, S.U., 2014. Drinking water quality and public health of selected towns in South Western Nigeria. Water Qual. Exposure Health 6, 143-153.

Degueurce, A., Tomas, N., Le Roux, S., Martinez, J., Peu, P., 2016. Biotic and abiotic roles of leachate recirculation in batch mode solid-state anaerobic digestion of cattle manure. Bioresour. Technol. 200, 388-395.

Elliot, A., Mahmood, T., 2012. Comparison of mechanical pretreatment methods for the enhancement of anaerobic digestion of pulp and paper waste. Water Sci. Technol. 84, 497-505.

Fang, Z., Liu, K., Chen, F., Zhang, L., Guo, Z., 2014. Cationic surfactant-assisted microwave- $\mathrm{NaOH}$ pretreatment for enhancing enzymatic hydrolysis and fermentable sugar yield from peanut shells. Bioresources 9, 1290-1302.

FAOSTAT. "Production and trade data for groundnuts (peanuts)". FAOSTAT, Food and Agricultural Organization of the United Nations, Statistics Division. 2013.

FAOSTAT. Food and Agricultural Organization Statistics. 2015.

Ghosh, S., Jha, P., Vidyarthi, A.S., 2014. Unravelling the microbial interactions in coal organic fermentation for generation of methane - a classical to metagenomic approach. Int. J. Coal Geol. 125, 36-44.

Herring, J.L., Narayanan, V.C., 2016. A comparative study on the utilization of corn pericarp and peanut hull in the production of ethanol and the impact on food economics. Food Nutr. Sci. 7, 1010-1020.

Iqbal, H.M.N., Kyazze, G., Keshavarz, T., 2013. Advances in the volarization of lignocellulosic materials by biotechnology: an overview. Bioresources 8, $3157-$ 3176.

Jaffar, M., Pang, Y., Yuan, H., Zou, D., Liu, Y., Zhu, B., et al., 2016. Wheat straw pretreatment with $\mathrm{KOH}$ for enhancing biomethane production and fertilizer value in anaerobic digestion. Chin. J. Chem. Eng. 24, 404-409.

Jain, S., Jain, S., Wolf, I.T., Lee, J., Tong, Y.W., 2015. A comprehensive review on operating parameters and different pretreatment methodologies for anaerobic digestion of municipal solid waste. Renewable Sustainable Energy Rev. 52, 142154.

Jang, J.-H., Ahn, J.-H., 2013. Effect of microwave pretreatment in presence of $\mathrm{NaOH}$ on mesophilic anaerobic digestion of thickened waste activated sludge. Bioresour. Technol. 131, 437-442.

Khoufi, S., Louhichi, A., Sayadi, S., 2015. Optimization of anaerobic co-digestion of olive mill wastewater and liquid poultry manure in batch condition and semicontinuous jet-loop reactor. Bioresour. Technol. 182, 67-74.

Leite, W.R.M., Gottardo, M., Pavan, P., Filho, P.B., Bolzonella, D., 2016. Performance and energy aspects of single and two phase thermophilic anaerobic digestion of waste activated sludge. Renewable Energy 86, 1324-1331.

Li, L., He, Q., Ma, Y., Wang, X., Peng, X., 2015. Dynamics of microbial community in a mesophilic anaerobic digester treating food waste: relationship between community structure and process stability. Bioresour. Technol. 189, 113-120. 
464

S.O. Dahunsi et al./Bioresource Technology 241 (2017) 454-464

Mao, C., Feng, Y., Wang, X., Ren, G., 2015. Review on research achievement of biogas from anaerobic digestion. Renewable Sustainable Energy Rev. 45, 540-555.

Maus, I., Koeck, D.E., Cibis, K.G., Hahnke, S., Kim, Y.S., Langer, T., 2016. Unraveling the microbiome of a thermophilic biogas plant by metagenome and metatranscriptome analysis complemented by characterization of bacterial and archaeal isolates. Biotechnol. Biofuels 9, 171.

Monlau, F., Barakat, A., Steyer, J.P., Carrere, H., 2012. Comparison of seven types of thermo-chemical pretreatment on the structural features and anaerobic digestion of sunflower stalks. Bioresour. Technol. 120, 241-247.

Monlau, F., Kaparaju, P., Trably, E., Steyer, J.P., Carrere, H., 2015. Alkaline pretreatment to enhance one-stage $\mathrm{CH} 4$ and two-stage $\mathrm{H} 2 / \mathrm{CH} 4$ production from sunflower stalks: mass, energy and economical balances. Chem. Eng. J. 260, 377-385.

Montingelli, M.E., Benyounis, K.Y., Quilty, B., Stokes, J., Olabi, A.G., 2016. Optimization of biogas production from the macroalgae Laminaria sp. at different periods of harvesting in Ireland. Appl. Energy 177, 671-682.

Polachini, T.C., Sato, A.C.K., Cunha, R.L., Telis-Romero, J., 2016. Density and rheology of acid suspensions of peanut waste in different conditions: an engineering basis for bioethanol production. Powder Technol. 294, 168-176.

Protot, A., Julien, L., Christophe, D., Partick, L., 2011. Sludge disintegration during heat treatment at low temperature: a better understanding of involved mechanisms with a multi-parametric approach. Biochem. Eng. J. 54, 178-184.

Riggio, S., Torrijos, M., Debord, R., Esposito, G., van Hullebusch, E.D., Steyer, J.P., et al., 2017. Mesophilic anaerobic digestion of several types of spent livestock bedding in a batch leach-bed reactor: substrate characterization and process performance. Waste Manage. 9, 129-139.
Tian, H., Duan, N., Lin, C., Li, X., Zhong, M., 2015. Anaerobic co-digestion of kitchen waste and pig manure with different mixing ratios. J. Biosci. Bioeng. 120, 51-57.

USDA. "Nutrition facts for peanuts, all types, raw, USDA Nutrient Data". Conde Nast, USDA National Nutrient Database, version SR-21. 2014.

Wang, S., Li, R., Yi, X., Fang, T., Yang, J., Bae, H., 2016. Isoprene production on enzymatic hydrolysate of peanut hull using different pretreatment methods. BioMed Res. Int. 4342892, 1-8.

Westphal, A., Kücke, M., Heuer, H., 2016. Soil amendment with digestate from bioenergy fermenters for mitigating damage to Beta vulgaris subspp. by Heterodera schachtii. Appl. Soil Ecol. 99, 129-136.

Xie, S., Frost, J.P., Lawlor, P.G., Wu, G., Zhan, X., 2011. Effects of thermo-chemical pretreatment of grass silage on methane production by anaerobic digestion. Bioresour. Technol. 102, 8748-8755.

Zahedi, S., Solera, R., Micolucci, F., Cavinato, C., Bolzonella, D., 2016. Changes in microbial community during hydrogen and methane production in two-stage thermophilic anaerobic co-digestion process from biowaste. Waste Manage. http://dx.doi.org/10.1016/j.wasman.2016.01.016.

Zonta, Z., Alves, M.M., Flotats, X., Palatsi, J., 2013. Modeling inhibitory effects of long chain fatty acids in the anaerobic digestion process. Water Res. 47, 1369-1380.

Zou, S., Wang, H., Wang, X., Zhou, S., Li, X., Feng, Y., 2016. Application of experimental design techniques in the optimization of the ultrasonic pretreatment time and enhancement of methane production in anaerobic codigestion. Appl. Energy 179, 191-202.

Zupancic, G.D., Ros, M., 2003. Heat and energy requirements in thermophilic anaerobic sludge digestion. Renewable Energy 28, 2255-2267. 